\title{
Tadeusz Szawiel
}

\section{Państwo jako instytucja i rzeczywistość społeczna}

\author{
DOI: $10.35757 /$ CIV.2007.10.08
}

\section{Wprowadzenie}

Czy redefinicja pojęcia państwa jest konieczna? $\mathrm{Na}$ tak sformułowany temat debaty "Civitas" ${ }^{1}$ odpowiedź jest prosta: nie. Pojęcie to nie wymaga ponownego zdefiniowania, bo gdyby pojawiły się okoliczności, które istotnie zmieniałyby państwo, jakim je znamy, lub tylko mu zagrażały, to znalazłoby to wyraz w języku. Pójdźmy za językiem: nadal używamy terminu „państwo” bez nowych przymiotników (na przykład „państwo polskie”, „państwo francuskie”). Wszystkie funkcjonujące określenia państwa odwołują się do od dawna znanych przymiotników: państwo westfalskie, prawa, liberalne, demokratyczne czy socjalne. Nie odczuwamy potrzeby dodania nowych przymiotników czy wprowadzenia neologizmów. Gdyby ktoś się posługiwał zwrotami postnowoczesne państwo francuskie, neopaństwo francuskie czy postpaństwo francuskie jako samo przez się zrozumiałymi, to spoglądano by na niego ze zdziwieniem lub usłyszałby zarzut, że nie wiadomo, o co chodzi. Kiedy natomiast słyszymy w debacie zwroty „postmodernizm”, „neokonserwatyzm”, „neoliberalizm”, to na ogół wiemy, o co chodzi i tylko w specjalnych sytuacjach domagamy się wyjaśnień.

Dlaczego pojęcie „państwo” obywa się bez nowych dookreśleń czy neologizmów? Ponieważ opisuje trwalsze struktury, które zro-

Tadeusz Szawiel - socjolog, doktor, pracuje w Instytucie Socjologii Uniwersytetu Warszawskiego, jest prezesem Instytutu Badań nad Podstawami Demokracji.

1 Debata „Civitas” Czy redefinicja pojęcia państwa jest konieczna? odbyła się 17 czerwca 2006 roku. 
dziły się wraz z nowoczesnością i trwają nadal. Nowoczesne państwo, dla którego symbolicznymi faktami sa Konstytucja Stanów Zjednoczonych z 1787 roku i rewolucja francuska $z 1789$ roku, to państwo narodowe, o określonej terytorialnie suwerenności. Nowoczesne państwo określaja instytucje obywatelstwa, reprezentacji (przedstawicielstwa) oraz reguły podejmowania wiążących decyzji. Wreszcie spełnia ono definicyjny warunek Maxa Webera: „państwem nazywamy instytucję (Anstaltsbetrieb) polityczna prowadzacą ciagła działalność, jeśli i o ile jej sztab administracyjny skutecznie rości sobie prawo do monopolu prawomocnego fizycznego przymusu w celu urzeczywistnienia jej porządków"2.

Od kiedy mówimy o państwie nowoczesnym, to określaja je następujace podstawowe parametry. Przede wszystkim jest to państwo narodowe, które w pewnym sensie stwarza naród. Więź narodowa jest najsilniejszą więzią tworzącą wspólnotę polityczną. Wraz $z$ nią pojawia się tożsamość narodowa, poczucie przynależności, identyfikowania się. Od połowy XIX wieku naród i więź narodowa są czymś oczywistym, ale nie trzeba idealizować tych procesów. Współczesne państwo oraz więź narodowa powstawały poprzez pot i łzy. Wprowadzenie standardu językowego w formie urzędowego języka oznaczało wyeliminowanie języków i dialektów lokalnych poprzez wprowadzenie obowiazku powszechnego i ustandaryzowanego kształcenia na poziomie podstawowym. Wzmacniał to powszechny pobór do wojska i podatki.

Po drugie, jest to państwo demokratyzujące się. Przez cały XIX wiek poszerzał się demos, coraz to nowe grupy zyskiwały pełnie praw politycznych, przede wszystkim wyborczych. W starych demokracjach proces ten zakończył się dopiero w połowie XX wieku (uzyskanie praw wyborczych przez kobiety we Francji i Szwajcarii). Niektórzy autorzy zwracaja uwage na pewnego rodzaju ewolucję koncepcji równości ${ }^{3}$. Równość wobec prawa, co dokumentuje hi-

\footnotetext{
2 M. Weber: Gospodarka i społeczeństwo, przekład D. Lachowska, Wydawnictwo Naukowe PWN, Warszawa 2002, s. 40.

3 Por. np. Ph.C. Schmitter: How to Democratize the European Union... and Why Bother?, Rowman \& Littlefield Publishers, Inc., Lanham 2000.
} 
storia XVIII wieku, równy udział w życiu politycznym (prawa wyborcze) - wiek XIX, równe szanse partycypacji i rzeczywisty udział na pewnym poziomie $\mathrm{w}$ dobrach ekonomicznych i kulturalnych (na przykład państwo opieki socjalnej - welfare state) to wiek XX, natomiast przełom XX i XXI wieku charakteryzuje się postulatami rozszerzenia równości wobec praw, tak aby wszyscy byli traktowani jako równi pod wszelkimi względami.

Po trzecie, jest to państwo, które w coraz większym zakresie przejmuje na siebie obowiąki socjalne, począwszy od reform Bismarcka pod koniec XIX wieku aż po welfare state drugiej połowy $\mathrm{XX}$ wieku.

Po czwarte, jest to państwo, pod którego adresem zgłaszane sa coraz większe oczekiwania i które niestrudzenie stymulowało takie oczekiwania, obiecując coraz więcej swoim obywatelom, najczęściej ponad możliwości ich spełnienia (government overload). Rezultatem był datujący się od końca lat sześćdziesiątych XX wieku spadek zaufania do instytucji publicznych.

Po piąte, jest to państwo, w którym wyraźnie wyodrębniaja się systemy funkcjonalne, przede wszystkim gospodarka oparta na pieniądzu i administracja oparta na władzy. Jest to państwo, w którym sfera spontanicznej regulacji (Lebenswelt) w coraz większym stopniu ulega wypłukiwaniu oraz ograniczaniu na rzecz regulacji administracyjnych i prawnych.

\section{Państwo demokratyczne}

Będzie tu mowa nie o każdym rodzaju państwa, ale o państwie liberalnej demokracji. By uniknać nieporozumień: demokracja jest tu rozumiana $\mathrm{w}$ sensie proceduralnym, wedle klasycznej definicji Josepha Schumpetera, rozwiniętej przez Roberta Dahla ${ }^{4}$.

4 R.A. Dahl: Polyarchy. Participation and Opposition, Yale University Press, New Haven - London 1971 , s. 3 . 
Przymiotnik „liberalna" odnosi się natomiast do trzech warunków, które dodatkowo musi spełnić demokracja proceduralna: (a) nie ma w niej obszarów wyłączonych spod demokratycznego władania i kontroli (takich jak na przykład wojsko); (b) występuje horyzontalna kontrola jednych urzędów przez drugie; (c) obecny jest bardzo szeroki zakres gwarancji pluralizmu politycznego i społecznego, wolności jednostek i grup oraz mniejszości kulturalnych, religijnych, etnicznych i innych.

Jakkolwiek jesteśmy przyzwyczajeni do wiązania demokratycznego typu ustroju $z$ państwem, to jednak demokracja (jako rodzaj ustroju politycznego) nie pokrywa się zakresowo z państwem. Możliwe sa niepaństwowe formy demokracji (na poziomie ponadpaństwowym). Formułowane sa argumenty na rzecz ewolucji Unii Europejskiej w kierunku niepaństwowej formy demokracji ${ }^{6}$. Zatem demokracja nie ogranicza się do oznaczenia ustroju politycznego państwa.

Państwo trwa, ponieważ nadal określaja je podstawowe struktury nowoczesności: demokracja i wartości wpisane na sztandarach Rewolucji Francuskiej - wolność, równość, braterstwo. Adam Przeworski zauważył, że podstawowe instytucje demokracji przedstawicielskiej zostały wymyślone mniej więcej do połowy XIX wieku A więc przez półtora wieku nie wymyślono żadnej nowej instytucji! Przeworski nie podaje dokładnie, jakie instytucje miał na myśli, ale trzeba mu przyznać, iż rzeczywiście od tego czasu nie pojawiła się żadna instytucja kluczowa dla ustroju demokratycznego. Natomiast na obrzeżach pojawiały się nowe instytucje, takie jak rzecznicy praw pewnego typu lub pewnych grup społecznych

\footnotetext{
5 L. Diamond: Developing Democracy. Toward Consolidation, Johns Hopkins University Press, Baltimore 1999, s. 10-11.

6 Por. M.F. Plattner: Competing Goals, Conflicting Perspectives, „Journal of Democracy” 2003,

t. 14, nr 4, s. 42-56; Ph.C. Schmitter: How to Democratize... .

$7 \mathrm{Z}$ wyjatkiem nigdy nie wprowadzonych w życie gwarancji współzarządzania przez robotników w Konstytucji Weimarskiej, wynalazek proporcjonalnej reprezentacji w latach sześćdziesiatych XIX wieku był ostatnia poważna (major) innowacja instytucjonalną. Wszystkie demokracje, które powstawały od końca XVIII wieku, włącznie $z$ powstałymi w ostatnich latach, łącza na różne sposoby i często w zróżnicowanym stopniu, już istniejące instytucje. B. Manin, A. Przeworski, S.C. Stokes: Elections and Representation, w: idem (red.): Democracy, Accountability, and Representation, Cambridge University Press, Cambridge 1999, s. 51.
} 
(najwcześniej rzecznicy praw obywatelskich) oraz tak zwane organizacje pozarzadowe (non-governmental organizations - NGOs). Te ostatnie sa instytucjami rzeczywiście nowymi, bo sytuuja się poza bezpośrednim zasięgiem instytucji państwowych, poza pragmatyka urzędnicza, a w coraz większym stopniu spełniają rolę egzekutywy organów państwa. Mówi się o sektorze non-profit jako o „odrębnym typie instytucjonalnym realizujacym zadania publiczne kontraktowane przez państwo"s. Dzieje się tak po części ze względu na finansowanie, w coraz większym stopniu, organizacji pozarządowych ze środków publicznych. W starych demokracjach $z$ dotacji publicznych pochodzi przeciętnie nieco ponad 60 procent ogółu środków organizacji pozarządowych, w Polsce 10-15 procent. Nie należy przy tym utożsamiać organizacji pozarządowych (NGOs, trzeci sektor) ze społeczeństwem obywatelskim jako takim. Organizacje pozarzadowe stanowia jedynie pewien - $\mathrm{w}$ istocie waski i bardzo szczególny - segment społeczeństwa obywatelskiego, znacząco różny od klasycznych dobrowolnych organizacji ${ }^{9}$.

W dającej się przewidzieć przyszłości państwa liberalnych demokracji nadal będa demokratyczne mimo nieustannie obecnego w debatach wattku „kryzysu demokracji”. Nie ma tu możliwości szerszej krytyki dyskursu „kryzysu demokracji”, ale warto na krótko odwołać się do historii, by pokazać, w jakim stopniu ogólne diagnozy stanu i perspektyw demokracji były w przeszłości uzależnione od czynników sytuacyjnych. Powrót do historii może być pomocny w uchronieniu się od presji tych czynników.

Po II wojnie światowej temat "kryzysu demokracji” okazał się szczególnie żywy w latach siedemdziesiątych, a ówczesne kłopoty i wyzwania, przed którymi stanęły demokracje Zachodu, skłaniały do alarmistycznych i pesymistycznych diagnoz.

\footnotetext{
8 E. Leś, S. Nałęcz: Potencjał ekonomiczny i społeczny sektora non-profit $w$ Polsce. Wybrane wyniki badan miedzynarodowych sektora non-profit, w: P. Gliński, B. Lewenstein, A. Sicinski (red.): Samoorganizacja społeczeństwa polskiego: trzeci sektor, Instytut Filozofii i Socjologii PAN, Warszawa 2002, s. 30.

9 Pisze o tym w: T. Szawiel: Społeczeństwo obywatelskie i kapitał społeczny $w$ Polsce na przełomie wieków (1995-2001), w: A. Miszalska, A. Piotrowski (red.): Obszary ładu i anomii. Konsekwencje i kierunki polskich przemian, Wydawnictwo Uniwersytetu Łódzkiego, Łódź 2006, s. 80-81.
} 
Oddajmy na chwile głos znanemu autorowi: „W ostatnich latach wnikliwi obserwatorzy na wszystkich tych trzech kontynentach dostrzegli mroczna przyszłość demokratycznej formy rządów. Przed odejściem ze stanowiska Willy Brandt - jak donoszono - wyraził przekonanie, że "Europa Zachodnia ma przed soba tylko 20 lub 30 lat demokracji; po tym okresie ześliźnie się ona bezwładnie w otaczajace ja morze dyktatury i nie ma wielkiej w tym różnicy, czy dyktat będzie pochodził $z$ jakiegoś politbiura, czy od jakiejś junty". Jeśli Wielka Brytania pozostanie nadal niezdolna do rozwiazania pozornie nierozwiazalnych problemów inflacji $z$ perspektywa depresji - jak zauważył pewien wyższy funkcjonariusz brytyjski - to "demokracja parlamentarna zostanie w ostatecznym rezultacie zastapiona przez dyktaturę". "Japońska demokracja załamie się - ostrzegał Takeo Miki pierwszego dnia po objęciu urzędu - jeśli nie zostana przeprowadzone zasadnicze reformy i nie zostanie przywrócone zaufanie narodu do polityki». Obraz, jaki znajduje odbicie w tych i innych oświadczeniach, wyraża dezintegracje porządku społecznego, załamanie się dyscypliny społecznej, bezsilność przywódców i alienację obywateli”. Następnie autor stwierdza, że jeszcze bardziej niepokojący jest „[...] zakres, w jakim okazuje się, iż proces przemyśleń musi obejmować nie tylko te znane dziedziny praktycznej polityki rządowej, lecz również podstawowe ramy instytucjonalne, poprzez które rządy funkcjonują. I to właśnie, co dziś podaje się w wątpliwość, to [...] także instytucje polityczne odziedziczone $z$ przeszłości"10.

Autorem cytowanych fragmentów jest politolog Samuel P. Huntington. Ponad trzydzieści lat temu Huntington przytoczył głośna opinię polityka, którego trudno posądzać o krótkowzroczność, powstała na fali ówczesnego pesymizmu i stanowiaca równocześnie jego najlepszy wyraz: „Demokracji w Europie Zachodniej pozostało co najwyżej 20 lub 30 lat" ${ }^{\prime 1}$. Minęło ponad trzydzieści lat od chwi-

\footnotetext{
${ }^{10}$ M.J. Crozier, S.P. Huntington, J. Watanuki: The Crisis of Democracy. Report on the Governability of Democracies to the Trilateral Commission. The New York University Press, New York 1975, s. 2 (31 maja 1975 roku przyjęto pełny projekt raportu na sesji Komisji Trójstronnej w Kioto, której przewodniczył Zbigniew Brzeziński).

11 Wypowiedź Willy'ego Brandta przytoczył „The Economist”, 23 marca 1974, s. 12.
} 
li, kiedy Willy Brandt ogłaszał swoją przepowiednię. W Europie już od dawna nie ma żadnego politbiura, o juntach nie pamięta nawet średnie pokolenie, a demokracja, chciałoby się powiedzieć, ma się dobrze, choć nie wszyscy by się z tym zgodzili.

Po dwudziestu pięciu latach od opublikowania raportu Kryzys demokracji Huntington stwierdził, że „być może najbardziej godne odnotowania jest to, że niezależnie od tego, czy demokracja była, czy nie była w kryzysie $\mathrm{w}$ krajach trilateralnych ${ }^{12}$, w połowie lat siedemdziesiatych, to wielu dobrze zorientowanych ludzi uważało, że jest"13. Po czym wymienił cały szereg zjawisk, które skłaniały wówczas do takiego sądu. Ale wydawcy książki, będącej w zamyśle próbą diagnozy stanu demokracji dwadzieścia pięć lat później, piszą, że wcześniejszy alarm dotyczący kryzysu demokracji, na który odpowiedzią był raport Michela Croziera, Samuela P. Huntingtona i Joji Watanuki, „obecnie wydaje się przesadny”.

Nie chodzi o to, że ówcześni autorzy popełnili błąd diagnozy. Wręcz przeciwnie, w swoich analizach zwracali uwage na rzeczywiste zjawiska. Co ciekawe, a dziś wręcz szokujace, Huntington niebezpieczeństw dla demokracji upatrywał we wzroście aktywności obywatelskiej na przełomie lat sześćdziesiątych i siedemdziesiatych, mającej osłabiać instytucje demokracji amerykańskiej. Błąd - czy, jak chcą niektórzy, przesada - polegał na nietrafnej ocenie wagi tych zjawisk dla demokracji w krajach trilateralnych i poddaniu się, nie dość krytycznie, duchowi pewnego momentu czasowego ${ }^{14}$. Autorzy trzech książek ${ }^{15}$, usiłujacy na podstawie bogatego materiału empirycznego odpowiedzieć na pytanie o źródła

\footnotetext{
${ }^{12}$ Będących przedmiotem analizy Komisji Trójstronnej (Trilateral Commission): państwa Ameryki Północnej, Europy Zachodniej i Japonia.

${ }^{13}$ S.J. Pharr, R.D. Putnam (red.): Disaffected Democracies. What's Troubling the Trilateral Countries?, Princeton University Press, Princeton 2000, s. XXIII.

${ }^{14}$ Zdarza się to intelektualistom dość często. Ciekawe, że na konferencji w Kioto (maj 1975 roku) Huntingtona krytykowali - trafnie, moim zdaniem - biznesmeni amerykańscy. To oni wskazywali, że w zjawiskach $z$ przełomu lat sześćdziesiątych i siedemdziesiątych znalazły wyraz cechy mające głębokie korzenie w tradycji amerykańskiej. $Z$ ich punktu widzenia nie było to nic nowego, a zatem nic szczególnie groźnego dla amerykańskiej republiki.

${ }_{15}$ H.D. Klingemann, D. Fuchs (red.): Citizens and the State, University Press, Oxford 1995; P. Norris (red.): Critical Citizens. Global Support for Democratic Governance, Oxford University Press, Oxford 1999; S.J. Pharr, R.D. Putnam (red.): Disaffected... .
} 
niezadowolenia obywateli ze współczesnych demokracji, jak ognia wystrzegaja się zwrotu „kryzys demokracji”. I maja po temu mocne powody. Jedna $z$ konkluzji, podzielana przez autorów wszystkich tych książek, jest stwierdzenie, że „nie znaleźliśmy dowodów na zmniejszanie sie przywiazania do zasad rządu demokratycznego lub demokratycznej władzy w naszych krajach. Wręcz przeciwnie, jeżeli już coś miało miejsce, to wzrost przywiązania do demokracji per se w ciagu ostatniego półwiecza"16. Przywiazanie do demokratycznych wartości jest na przełomie wieków w krajach liberalnych demokracji większe niż kiedykolwiek. Wydaje się, że dziś żaden polityk pokroju Willy'ego Brandta nie zaryzykowałby twierdzenia, iż „przed upływem najbliższych trzydziestu lat zachodnie demokracje pogrążą się w morzu fundamentalistycznych (lub, jak kto woli, autorytarno-prawicowych) reżimów, a czy to będzie taka, czy inna teokracja, to nie będzie miało znaczenia". Hipoteza o fundamentalnej zmianie stosunku obywateli do państw liberalnych demokracji nie znalazła potwierdzenia w danych, a to oznacza, że taka zmiana nie nastapiła. Niezależnie od rozczarowania możliwościami demokratycznej partycypacji, rezultatami polityki w ich krajach lub działaniami aktorów politycznych, niezadowolenie nie uogólniło się na stosunek do demokracji. Nie ma też podstaw, by uważać, że demokracje zachodnie nie będą w stanie sprostać nowym wyzwaniom, w obliczu których stoją.

\section{Zmiany}

Jednak zmiany zachodza - wewnętrzne i zewnętrzne. Te wewnętrzne nie zagrażaja państwu jako systemowi instytucji, ale osłabiaja jego fundamenty społeczne i kulturowe. Państwo staje się coraz większe i silniejsze. Procesy dostosowawcze odbywają się przez rozrost jego instytucji. Państwo zwiększa swe zadania, dostosowu-

${ }^{16}$ S.J. Pharr, R.D. Putnam (red.): Disaffected..., s. 7. 
jąc się do oczekiwań, ale także je stymulujacc. Wzrasta liczebność administracji państwowej, rośnie też i utrzymuje się na wysokim poziomie udział wydatków publicznych w PKB (w Polsce około 46 procent) ${ }^{17}$. Wraz $z$ tym wzrasta bezpośrednia i pośrednia władza administracji ${ }^{18}$, a od niej zależy, co się dzieje w innych systemach społecznych (edukacja, służba zdrowia, systemy emerytalno-rentowe). Ma to konsekwencje, które moga się nie podobać (jak rozmiar władzy urzędu i rosnąca atrakcyjność władzy poprzez urząd publiczny). Sprawia to, że preferowanym typem zmiany społecznej (reformy) jest zmiana poprzez władzę administracyjna, która staje się techniczna, celowo-racjonalna, a cele często wyznaczaja wąskie grupy wsparte zapleczem eksperckim, kosztem innych modeli zmiany, takich jak mobilizowanie opinii publicznej i budowanie woli politycznej. Pojawia się takie zjawisko jak interes własny administracji, niekontrolowany przez agendy politycznej mobilizacji i reprezentacji (partie polityczne, parlament, rzad).

Równocześnie mamy do czynienia $z$ osłabieniem jednostki i dobrowolnych stowarzyszen. Państwo pochłania zasoby, dusi indywidua i grupy, osłabia zakorzenienie jednostki, tkankę obyczajów oraz lokalnych kultur, osłabia życie (Lebenswelt).

Zmieniają się też warunki zewnętrzne. Jednak - wbrew temu, co często się głosi - nie mają one znaczącego wpływu na państwa. Nie ma takiego procesu jak „zmierzch państwa narodowego” i w dającej się przewidzieć przyszłości nie grozi nam taki zmierzch ${ }^{19}$. Globalizacja nie ma aż takich skutków dla suwerenności państw, jak to sugeruja medialne debaty. Procesy globalizacji gospodarczej, ułatwień komunikacyjnych czy nowe globalne media (Internet) stanowia raczej nowe narzędzia i stwarzaja szanse do wykorzystania przez państwa, niż wymuszają ograniczenia suwerenności

\footnotetext{
${ }_{17} \mathrm{~W}$ państwach OECD średni udział wydatków publicznych w PKB wynosił w latach sześćdziesiatych 30,0 procent, w siedemdziesiatych $-37,5$ procent, w osiemdziesiatych $-44,5$ procent, a w dziewięćdziesiatych - 46,3 procent (http://www.nbportal.pl/pl/np/bloki/gospodarka/ wzrostaredystrybucja).

18 Jako jeden $z$ pierwszych zwrócił na to uwage Max Weber w analizach biurokracji.

${ }^{19}$ Por. przegląd argumentów w: E. Wnuk-Lipiński: Świat międzyepoki, Społeczny Instytut Wydawniczy Znak, Instytut Studiów Politycznych PAN, Kraków - Warszawa 2004, s. 159-180.
} 
bądź wyjmowanie spod ich kontroli ważnych funkcji czy obszarów. Jako przykłady takiego ograniczania suwerenności podaje się ponadnarodowe korporacje i przepływy kapitału (tu szczególnie spektakularny jest kapitał spekulacyjny). Państwa zachowały jednak wystarczajacce instrumenty kontroli ponadnarodowych korporacji, a możliwości wpływu tych korporacji na gospodarke i politykę wynikają raczej ze słabości w wykorzystaniu stojących do dyspozycji państw instrumentów, takich jak regulowanie lobbingu czy wypracowanie skutecznej polityki gospodarczej. Kontrola przepływu kapitału czy ponadnarodowych korporacji jest raczej kwestia polityczna (decyzji politycznych i woli politycznej) niż problemem strukturalnym i instytucjonalnym państwa. W końcu siła grup interesu nie jest dowodem jakiejś immanentnej niemożności państwa, ale problemem polityki konkretnego rząu w ramach państwa. Potęga związków zawodowych w Wielkiej Brytanii pod koniec lat siedemdziesiątych nie świadczyła o jakichś nieprzezwyciężalnych ograniczeniach możliwości demokratycznego państwa. Zmiana polityki przez rząd Margaret Thatcher na początku lat osiemdziesiątych w krótkim czasie ograniczyła potęgę związków. Natomiast uleganie znaczącym grupom interesów, jak rolnikom we Francji czy górnikom w Polsce, jest rezultatem wyborów politycznych i wynikającej $z$ nich polityki społecznej, a nie jakichś istotnych ograniczeń instytucjonalnych demokratycznego państwa narodowego.

Nie zmieniaja też zasadniczo sytuacji państw narodowych organizacje ponadnarodowe. Państwa nie wyzbywaja się na ich rzecz swoich kompetencji, lecz je deleguja. Teoretycznie moga zawsze sie $z$ tego wycofać. Poza tym państwa rezygnuja $z$ bezpośredniej kontroli, kiedy im się to opłaca $\mathrm{w}$ długim okresie. Jednak $z$ ważnych prerogatyw - takich jak polityka podatkowa, polityka społeczna czy środki przemocy - nie rezygnują. Unia Europejska jest organizacją opartą na traktatach międzyrządowych i jakkolwiek można się spierać o instytucjonalna „naturę" Unii, to wśród politologów panuje zgoda, że Unia nie jest państwem w żadnym znanym 
nam znaczeniu pojęcia i jest mało prawdopodobne, by ewoluowała w kierunku jakiejkolwiek postaci państwa federalnego. Nie dlatego, że nie chca tego elity polityczne (bo jakaś część pewnie by chciała), ale dlatego, że działaja tu siły przekraczające możliwości politycznego planowania i mobilizacji, takie jak historia i kultura. Przedsmak tego typu ograniczeń daja niedawne referenda konstytucyjne we Francji i Holandii.

Organizacje ponadpaństwowe sa raczej organizacjami regulujacymi (jak Światowa Organizacja Handlu) niż władczymi. Podobnie - ani Organizacja Narodów Zjednoczonych, ani Komisja Europejska nie sa $\mathrm{w}$ gruncie rzeczy instytucjami władczymi, lecz regulującymi. Przywołuja państwa do porządku w sytuacji, gdy one same (suwerennie) zgodziły się na to. Jako przykład moga posłużyć działania Komisji w sytuacji przekraczania progów deficytów budżetowych przez kraje członkowskie. Ewentualna akceptacja sankcji nie jest przejawem ograniczenia suwerenności, ale kalkulacji kosztów. Teoretycznie każdy kraj może wystapić z Unii. Państwa zachowuja suwerenność w sprawie podstawowej decyzji: opłaca się podporządkować (i ponieść koszty) czy też wyjść z Unii (i też ponieść koszty, tyle że inne i znacznie większe).

\section{Podstawowe wartości nowoczesności}

Druga podstawa nowoczesnego państwa demokratycznego sa wartości, ale rozumiane nie jako przekonania jednostki, lecz jako zasady organizujące instytucje będące fundamentem państwa demokratycznego. Te wartości określił projekt nowoczesności. Wypada zatem zacząć od pytania: kiedy nastała nowoczesność i kiedy się skończy? Szczególnie trafna w tym kontekście wydaje się argumentacja amerykańskiego politologa Herberta Kitschelta. Przekonuje on, że nie przekroczyliśmy horyzontu nowoczesności, której symboliczne narodziny przypadaja na rok 1789, ponieważ nadal uniwersum możliwych programów politycznych dobrze od- 
daje hasło Rewolucji Francuskiej „wolność, równość, braterstwo”20. Zdaniem Kitschelta nie wykroczyliśmy poza horyzont tych trzech wartości, ponieważ instytucje, które je ucieleśniaja, sa nadal podstawowymi instytucjami liberalnych demokracji. Kitschelt krótko i sugestywnie pokazuje, w jaki sposób te trzy wartości sa przekładane na praktykę społeczna przez trzy instytucje.

Wolność przekłada i instytucjonalizuje rynek, oparty na wolnej i dobrowolnej wymianie między jednostkami ${ }^{21}$. Równość - to kolektywne organizacje (państwo) $z$ jakiegoś rodzaju centralnym mechanizmem alokacji (na przykład zasadą większości) jako źródłem decyzji obowiązujących wszystkich członków danej organizacji. Wolność i równość tworza jeden wymiar o dwóch biegunach. Pierwszym biegunem tego wymiaru jest instytucja centralnej alokacji zasobów i odpowiadająca jej polityka socjalistyczna, drugim - spontaniczna alokacja zasobów (rynek) oraz odpowiadająca jej polityka kapitalistyczna. Osobny wymiar tworzy braterstwo, które urzeczywistniaja wspólnoty oparte na bezpośrednich kontaktach. Kitschelt wyróżnia dwa główne typy wspólnot: na jednym biegunie - wspólnotę, którą nazywa libertariańską, opartą na dobrowolnym i równym uczestnictwie wszystkich, na drugim biegunie - wspólnotę paternalistyczną, opartą na hierarchii i przymusowym członkostwie, w której jednostki nie maja równych praw. Oba wymiary - wolności i równości oraz braterstwa - których nie da się zredukować do siebie, tworzą do dziś dwuwymiarowa przestrzeń możliwych problemów i dylematów oraz praktyk poli-

\footnotetext{
${ }^{20}$ H. Kitschelt: The Transformation of European Social Democracy, Cambridge University Press, Cambridge 1994, s. 9-12.

21 Juan J. Linz i Alfred Stepan zwracaja uwage, że istnieje logiczny związek między demokracja a rynkiem. Rynek jest warunkiem koniecznym tej formy ustrojowej: ,[... nie przedstawiono nigdy żadnych dowodów wskazujących, żeby kiedykolwiek istniała społeczność polityczna [polity] spełniajaca kryteria naszej definicji skonsolidowanej demokracji w gospodarce nakazowej [command economy]. [...] Czy istnieje jakieś teoretyczne wyjaśnienie tego bezwyjątkowego empirycznego faktu? Uważamy, że tak. W płaszczyźnie teoretycznej zakładamy, że jakiś istotny stopień autonomii rynku i zróżnicowanie form własności w gospodarce są warunkiem koniecznym, by wytworzyć niezależne i witalne społeczeństwo obywatelskie będące w stanie wnieść swój wkład w demokracje", w: J.J. Linz, A. Stepan: Problems of Democratic Transitions and Consolidation. Southern Europe, South America, and Post-Communist Europe, The Johns Hopkins University Press, Baltimore - London 1996, s. 11.
} 
tycznych. Nie potrafimy bowiem odpowiedzieć na pytania o kształt porządku społecznego, podstawowych instytucji państwa, typów więzi społecznych i kultury, w których nie miałyby zastosowania pojęcia równości, wolności i braterstwa (solidarności). Nadal są one horyzontem wszelkiego możliwego w tej sferze namysłu.

Tak długo, jak długo będzie obecna ta dwuwymiarowa przestrzeń, będą również obecne problemy i dylematy, przed którymi stoja liberalne demokracje. Nie zniknie pytanie, w jakim stopniu to rynek ma regulować rozdział społecznie cenionych dóbr, a w jakim organizacje centralne (państwo i jego agendy). Podobnie nie zniknie pytanie o kształt wspólnoty: zastanej - opartej na podporządkowaniu, kontroli, jakiejśs hierarchii, czy też dobrowolnej - opartej na równych prawach. Dylematy te nie ograniczaja się do pytań typu „mniej czy więcej?”, sa to również pytania typu „jak?”. Nie tylko „więcej rynku czy państwa?”, ale też „jakiego państwa, jakiego rynku i jakiej wspólnoty?”. Sa to właśnie pytania o wolność, równość i braterstwo.

W przypadku równości państwo ze swoimi mechanizmami redystrybucji nie tylko stoi przed pytaniem o skalę (na przykład odsetek dochodu narodowego, który jest w dyspozycji agend publicznych wszystkich szczebli) oraz o kierunek redystrybucji, ale także o definiowanie i w jeszcze większym stopniu uznawanie nowych nierówności. Nierówności nie sa czymś, co po prostu się widzi. Widzi się je w zależności od wartości i interesów. Na przykład zwraca się uwagę, że w rozwiniętych liberalnych demokracjach pojawia się nowy konflikt: między pokoleniem rencistów i emerytów, których odsetek rośnie wraz ze wzrostem przeciętnego trwania życia (a w związku z tym zwiększają się koszty systemów opieki społecznej i ubezpieczeń społecznych) a pokoleniem ludzi młodych (14-24 lata). Zabezpieczenie społeczne emerytów i rencistów zazwyczaj odbywa się kosztem wydatków na kształcenie i rozwój młodzieży, zwłaszcza tam (na przykład w Europie), gdzie szkolnictwo wyższe jest finansowane niemal wyłącznie przez państwo. 
W przypadku równości praw przedmiotem debaty publicznej i sporów politycznych jest ostatnio prawo do swobody ekspresji w przestrzeni publicznej dla gejów i lesbijek, a następnie równość w dostępie do małżeństwa oraz do wychowywania dzieci. Czy jest to kwestia kulturowa, czy nie? Co tu jest obyczajem, który może się zmienić, a co czymś więcej? Czy odmowa praw politycznych (wyborczych) kobietom, dostępu do wpływu na władzę w XIX wieku, jest analogiczna do odmowy gejom i lesbijkom zawierania małżeństw w wieku XXI? Czy ówczesne sufrażystki można uznać za lesbijki XIX wieku, czy też są to sytuacje nieporównywalne?

Czy istnieje jakaś granica równych praw dla wszystkich pod wszelkimi względami? W wielu krajach dzieci uzyskały prawo do skarżenia rodziców przed sądem. Państwo w coraz większym stopniu reguluje stosunki nie tylko między małżonkami, ale także między rodzicami i dziećmi. Gdzie przebiega granica oddzielająca ochronę praw i interesów dziecka od realizacji partykularnych interesów państwa związanych $z$ wartościami i przekonaniami, których moga nie podzielać nie tylko konkretni rodzice, ale także znaczne grupy obywateli znajdujacych się w sytuacji trwałych mniejszości? Jak wytyczyć granicę rozszerzania praw dziecka: przecież wcale nie jest absurdalne przyznanie dzieciom prawa skarżenia rodziców i domagania się odszkodowania za błędy wychowawcze czy konkretne decyzje rodziców (na przykład przeprowadzkę do innego miasta ze względu na lepsze możliwości zarobkowania, gdzie jednak szkoła i środowisko szkolne sa dużo gorsze), jeżeli dziecko potrafi udowodnić przed sąem, że poniosło straty czy niepowodzenia, które nieodwracalnie wpłynęły na jego szanse życiowe oraz na to, kim jest. Problem równych praw i państwa jako agendy obrony praw oraz rzecznika interesów można uogólnić: jakie sa granice (lub odwrotnie: obowiązek) prawnej i biurokratycznej ingerencji w sfery ludzkiej i społecznej spontaniczności lub regulacji przez tradycję i obyczaj?

Jeśli chodzi o wolność, to dziś nie chodzi już o pytanie „rynek czy też coś innego?”, jakkolwiek w przeszłości w co najmniej 
dwóch krajach rynek doznał znacznego ograniczenia (Wielka Brytania i Szwecja). Istotniejsze staje się pytanie: jaki rynek? Przy czym chodzi nie tyle o pytanie ,jak dalece regulowany, kontrolowany?", ile o to, jak regulowany. Na przykład w dziedzinie ekologii - czy przez nakładanie podatków na produkty „zanieczyszczające środowisko" (benzyna), czy też poprzez wprowadzanie standardów emisji spalin, stopnia czystości rozmaitych procesów itp.

W kwestii braterstwa problemem sa przekształcenia sfery obywatelskiego zaangażowania. Czy mamy do czynienia $z$ systematycznym osłabieniem civic community, jak twierdzi Robert Putnam, czy też $z$ jej przekształceniami? Czy klasyczne organizacje ${ }^{22}$ społeczeństwa obywatelskiego będą wysychały, systematycznie wypierane przez sprofesjonalizowane NGOs, stajace się $\mathrm{w}$ coraz większym stopniu egzekutywami państwa, czy też nowe impulsy zrewitalizuja sfere obywatelska, jak to już raz miało miejsce pod koniec XIX wieku? Czy organizacje społeczeństwa obywatelskiego nadal będą $\mathrm{w}$ stanie generować kapitał społeczny, czy też jego brak będzie systematycznie kompensowany przez celowo-racjonalne działania NGOs i administracji publicznej? Instytucje ucieleśniajace braterstwo maja podstawowe znaczenie dla swobód i wolności politycznych w demokratycznym państwie (zwłaszcza różne postaci samorządu). Warto przywołać $\mathrm{w}$ tym miejscu świadectwo Alexisa de Tocqueville'a: „A przecież właśnie w gminie tkwi siła wolnych społeczeństw. Instytucje gminne sa dla wolności tym, czym dla nauki sa szkoły podstawowe: sprawiaja, że wolność staje się dostępna dla ludu, pozwalaja mu zasmakować w swobodnym jej praktykowaniu i przyzwyczajają go do posługiwania się nią. Bez pomocy instytucji gminnych naród może stworzyć sobie wolny rząd, lecz nie będzie w nim ducha wolności”23.

\footnotetext{
${ }^{22}$ R. Putnam: Bowling Alone. Malejacy społeczny kapitał Ameryki, przekład M. Pietrzak-Merta, „Res Publica Nowa” 1996, nr 6 (szczególnie odróżnienie organizacji wtórnych, klasycznych, od organizacji tzw. trzeciego rzędu).

${ }^{23}$ A. de Tocqueville: O demokracji $w$ Ameryce, przekład B. Janicka, M. Król, Społeczny Instytut Wydawniczy Znak, Fundacja im. Stefana Batorego, Kraków - Warszawa 1996, t. 1, s. 62.
} 


\section{Uwagi końcowe}

W przedstawionej tu perspektywie przyszłość państwa zależy od dwóch elementów dziedzictwa nowoczesności: demokracji przedstawicielskiej oraz instytucji ucieleśniających i implementujących podstawowe wartości (wolność, równość, braterstwo). Od dalszych losów tych instytucji zależy przyszłość państwa liberalnej demokracji. Czy możliwa jest niepaństwowa forma demokracji, to znaczy demokratycznie zorganizowana społeczność polityczna nie będąca państwem, jakim je znamy? Nie istnieje przekonująca odpowiedź na to pytanie. Przewidywania takie sa formułowane $\mathrm{w}$ środowisku politologów zajmujących się Unią Europejska, jej przyszłością instytucjonalną i demokratyzacją. W takim ujęciu Unia ewoluowałaby w kierunku nowej formy politycznej. Dwie takie formy doczekały się bardziej wnikliwych analiz: plurilateralne neośredniowieczne imperium (Jan Zielonka ${ }^{24}$ ) oraz niepaństwowa demokracja $\mathrm{w}$ formie kondominium lub konsorcjum (Philippe Schmitter). Na pewno taka nowa forma nie jest możliwa bez nowych instytucji ${ }^{25}$. Szkicowe projekty takich instytucji przedstawia Schmitter w sferze obywatelstwa (na przykład uniwersalne obywatelstwo, to jest od momentu urodzenia ${ }^{26}$ ), instytucji przedstawicielskich (na przykład specjalny podatek służacy finansowaniu instytucji interest intermediation) oraz $\mathrm{w}$ systemie podejmowania decyzji (na przykład kurialny system podejmowania decyzji ${ }^{27}$ ). Członków różnicowałby też zakres akcesji i, konsekwentnie, zakres obowiąków. Jednak, jak dotąd, nowatorskie pomysły idące $\mathrm{w}$ kierunku nowych, niepaństwowych form politycznych nie przebijaja się poza dyskurs naukowy. Trudno też spe-

${ }^{24}$ J. Zielonka: Europa jako imperium. Nowe spojrzenie na Unie Europejska, Polski Instytut Spraw Międzynarodowych, Warszawa 2007.

${ }^{25}$ Pod względem stopnia konkretności propozycji wyróżnia się książka Philippe’a Schmittera How to Democratize the European Union... (zob. przypis 3). Z niej czerpie przytoczone niżej przykłady.

${ }^{26}$ Wówczas prawa wyborcze przysługują od momentu urodzenia. Prawa te wykonywaliby do pewnego momentu rodzice. Ma to interesujace konsekwencje.

${ }^{27}$ Członkowie Unii dziela się na trzy kategorie według wielkości populacji. Decyzja uznawana jest za podjęta, jeżeli uzyska większość w każdej z trzech kurii. 
kulować, czy kiedykolwiek się przebiją. Jeszcze trudniej przedstawia się sprawa wolności, równości i braterstwa (rynku, centralnej (re)dystrybucji i form społecznego zorganizowania). Trudno sobie nawet wyobrazić, na czym mogłoby polegać „przekroczenie” tych wartości. Żadna nowa „tabela wartości” nie wyłania się nawet zza najdalszego horyzontu.

Godna uwagi wydaje się tu jeszcze jedna oś wykraczająca poza problematykę demokratycznych instytucji. Prowizorycznie można by zidentyfikować jej bieguny jako „wzmocnienie życia” i „osłabienie życia” oraz, odpowiednio, państwa wzmacniające i osłabiające życie. Ponieważ nie ma tu miejsca na szersze objaśnienia, muszą wystarczyć przykłady. Państwem „wzmocnienia życia” byłyby starożytne Ateny, państwem „osłabienia życia” - Sparta. We współczesnych demokracjach również można wyróżnić te mniej i bardziej dynamiczne, kreatywne, wzorcotwórcze, o większej sile przyciagania i integrowania czy woli przywództwa. Ateny zostawily po sobie dziedzictwo, które określa nas do dziś. Rozumiemy je, bo ono kształtowało nas bez naszej wiedzy, jako w pewnym sensie rozpuszczone $\mathrm{w}$ naszej kulturze. Ale też formułujemy pod jego adresem nasze własne pytania, oczekujac na nie odpowiedzi. Nowe pytania wywołuja nowe odpowiedzi. W ten sposób to dziedzictwo żyje. Jeżeli dziś idziemy do teatru, by obejrzeć inscenizację Antygony, to nie dlatego, że tak trzeba, ale dlatego, że tragedia Sofoklesa mówi coś o nas samych, bo jest odpowiedzia na nasze pytania. O spuściźnie Sparty trudno byłoby coś takiego powiedzieć. Na pewno źródła różnic są złożone. Nie można ich sprowadzać ani do kultury, ani do instytucji. Wydaje się, że kluczowe może być tu pojęcie form życia, takich, które sprzyjaja kreowaniu liderów kulturowych, społecznych i politycznych. Forma życia to więcej niż wartości, przekonania czy zachowania. W debatach nad przyszłością Unii Europejskiej czy Stanów Zjednoczonych oś „wzmocnienie - osłabienie życia" i związane $z$ nia problemy od jakiegoś czasu zaczynaja być obecne, choć pojęcia, w jakich się wyrażaja, są bardzo różne. W każdym razie problem porządku demokratycznego 
wzmacniającego życie może się okazać ważny. W gruncie rzeczy był to problem, którego szczególna postać rozważał de Tocqueville w końcowych rozdziałach $O$ demokracji $w$ Ameryce, kiedy analizował, jak „demokratyczny układ społeczny szczególnie ułatwia powstanie despotyzmu” oraz gdy roztaczał swoja wizję: „[...] widzę nieprzebrane rzesze identycznych i równych ludzi, nieustannie kręcących się w kółko w poszukiwaniu małych i pospolitych wzruszeń, którymi zaspokajaja potrzeby swego ducha. [...] Ponad wszystkimi panuje na wyżynach potężna i opiekuńcza władza, która sama chce zaspokoić ludzkie potrzeby i czuwać nad losem obywateli. Ta władza jest absolutna, drobiazgowa, pedantyczna, przewidująca i łagodna. [...] W ten sposób wolną wolę ludzką czyni z każdym dniem bardziej nieużyteczną i sprawia, że przestaje się ona objawiać. Ogranicza jej teren działania, stopniowo pozbawiając człowieka nawet samego siebie"28. Choć we współczesnych liberalnych demokracjach można rozpoznać elementy wizji de Tocqueville'a, to jednak zdołały one ochronić ducha wolności i kreatywności dzięki systemowi instytucji, które on sam starał się opisać. Podobnie - liberalne demokracje na początku XXI wieku wciąz szukaja nowych i rewitalizuja stare wehikuły amplifikacji życia.

\footnotetext{
${ }^{28}$ A. de Tocqueville: O demokracji..., t. 2, s. 329.
} 